\title{
Earmark lobbyists 'paid \$60 million a year'
}

Washington. US universities spend $\$ 60$ million a year paying Washington lobbyists to help them to bypass the scientific peer review process and attract earmarked funding for research facilities and projects, a congressional committee was told last week.

William Ihlandfeldt, vice-president of Northwestern University, Illinois, told a hearing of the House of Representatives Science, Space and Technology Committee, chaired by George Brown (Democrat, California), that his institution pays between $\$ 300,000$ and $\$ 400,000$ a year on lobbying for funds in Washington, and that "more than fifty, I'd say a couple of hundred" other institutions do the same. David Minge (Democrat, Minnesota) noted that this implied a total spend of $\$ 60$ million a year.

The news will not surprise the restaurateurs on whose premises the lobbyists many of them former congressmen or their staff - ply their trade. But it shocked some members of the committee. Harris Fawell (Republican, Illinois), co-chairman of the informal "pork-busters group" in Congress, described it as a "devilish situation".

M. R. C. Greenwood of the White House Office of Science and Technology Policy told the hearing that growth in earmarking "has the potential of destroying the process" that funds scientific research in the United States. But she declined to promise any action by the administration to stop it, and appeared to pass the buck by describing it as a problem first for Congress, and then for the universities that benefit.

Brown wants the administration to issue an executive order reminding federal agencies and government departments that they are not obliged to obey the report language on budget bills, which contains the earmarks. Greenwood declined to offer this, saying that "we have not been able to find a single solution to the problem".

In a follow-up hearing the next day on earmarks by the Department of Defense, John Silber, the president of Boston University, told the committee that he spent $\$ 400,000$ each year on the services of a lobbyist, Gerald Cassidy, who had come to his attention through his work for nearby Tufts University. Silber said he had closed a Washington liaison office costing $\$ 250,000$ a year to run, and turned to Cassidy instead.

The total cost of individual universities' lobbying efforts is difficult to estimate. But as neither Boston nor Northwestern are likely to be the biggest spenders, and well over a hundred schools are active in the earmark hunt, the $\$ 60$ million figure is probably not far from the truth.

"In effect, you robbed banks because that's where the money is," Brown told Ihlandfeldt and other university witnesses. "The agencies fund it, as you have heard, because they don't want to upset senior congressmen, but there is no law or reason to it. We are not condemning the process because it produces bad science: we are condemning it because it is unfair."

After vigorously defending the way in which Boston University obtained congressional support for its proposed photonics research centre (see Nature 371, 273; 1994) without going through the normal peerreviewed channels, Silber was rebuked by Martin Hoke (Republican, Ohio). "It is clear that you have decided there is an agenda for Boston University which is of greater importance than the agenda of the United States Congress," he told the Boston president.

Earlier, the hearing heard that the Environmental Protection Agency (EPA) had accepted instructions over the telephone from congressional staff to place three projects at the University of Arkansas, Louisiana State University and the University of North Dakota respectively. In each case, the projects had not been earmarked in the report language of the EPA's budget bill and were therefore assumed to be open to competitive application.

To some, this suggests the possible existence of a pot of 'invisible' earmarks of indeterminate size, not included in report language or noted in previous earmark tallies and perhaps, say opponents, testing the boundaries of propriety. John Cannon, assistant administrator of EPA, told the hearing that he was not briefed to explain these cases. But Brown's committee is unlikely to let the matter rest.

\section{Virtual reality faces hardware gap}

Washington. Awkward headsets and other hard-to-use equipment threaten to obstruct the progress of virtual reality technologies, according to a report published last week by the US National Academy of Sciences on how the federal government should ap proach interactive computer systems.

The 500-page report, prepared for the government by the National Research Council (NRC), the research arm of the academy, says that virtual reality is largely driven by computer software specialists who tend to ignore the deficiencies of the hardware.

"The importance of adequate hardware tends to be underplayed by the [virtual reality] community," the academy says. "If the comfort of virtual reality systems (particularly head-mounted displays) cannot be radically improved, the practical usage of these systems will be limited to emergency situations or to very short time periods."

Despite the excessive hype for virtual reality, the report concludes that the technology has genuine potential in a wide range of applications, and is engaging the serious research interest of scientists, social scientists and engineers.

Development of virtual reality systems is at present being driven by pressures from two extremes: at one end, the entertainment industry is pursuing low-cost systems, while the military is building highly sophisticated systems with little regard to cost. But the report identifies four sets of intermediate applications - industrial use, medicine, hazardous operations and training - as the most promising domains for the use of virtual reality in the long run.

It proposes that the government should set up "national research and development teams" for different application areas to overcome "organizational barriers" between different agencies, universities and indus-

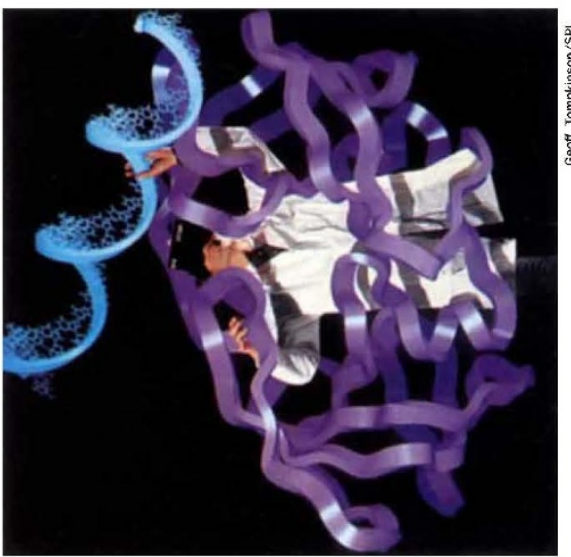

Microworld: technology opens new opportunities for biologists.

trial companies. It identifies these as a greater problem than relations between different disciplines, such as engineering, computer science and psychology, which are working together on virtual reality.

The report also suggests that the US government should establish a set of accepted standards, or an independent laboratory for formal evaluation of virtual reality equipment. "In general, technology and equipment are not being adequately evaluated," it says. The report identifies various points on which federal research should focus, but makes no recommendations on the money that needs to be spent.

The National Aeronautics and Space Administration, the National Science Foundation and various defence and intelligence agencies jointly commissioned the report from the NRC in 1992. It was conducted by a panel of engineers and scientists chaired by Nathaniel Durlach of the electrical engineering and computer science department at the Massachusetts Institute of Technology.

c. $\mathbf{M}$ 